\title{
Upaya Eliminasi Residu Logam Berat pada Sapi Potong yang Berasal Dari Lokasi Tempat Pembuangan Akhir Sampah dengan Pemeliharaan Secara Konvensional
}

\author{
Sudiyono \\ Jurusan/Program Studi Peternakan Fakultas Pertanian,Universitas Sebelas Maret \\ Jl. Ir. Sutami 36A, Surakarta 57126
}

\begin{abstract}
ABSTRAK
Penelitian bertujuan untuk mengetahui kandungan logam berat $\mathrm{Pb}$ dan $\mathrm{Hg}$ dalam sampah organik dan cara eliminasi residu logam berat $\mathrm{Pb}$ dari produk sapi potong (daging dan organ viscera). Dua ekor sapi Peranakan Ongole (PO) jantan digunakan dalam penelitian ini. Ransum yang diberikan berupa hijauan rumput Raja dan konsentrat komersial Nutrifeed. Pemeliharaan dilakukan selama tiga bulan. Pada awal pemeliharaan dilakukan pengambilan sampel darah dan feses sapi-sapi tersebut, selanjutnya diambil setiap dua minggu sekali sebanyak tujuh kali pengambilan. Pada akhir pemeliharaan sapi-sapi teresebut dipotong dan diambil sampel daging bicept femoris, hati, ginjal dan usus untuk dianalisis kandungan $\mathrm{Pb}$. Hasil penelitian menunjukkan bahwa sampah organik terkontaminasi $\mathrm{Pb}$, tetapi tidak terkontaminasi $\mathrm{Hg}$. Kadar $\mathrm{Pb}$ pada darah dan feses bervariasi dan cukup tinggi, sedangkan pada produk sapi potong (daging dan viscera) masih terkandung $\mathrm{Pb}$ yang cukup tinggi dan masih di atas batas aman untuk dikonsumsi. Kesimpulan yang dapat diambil adalah bahwa waktu pemeliharaan konvensional selama 3 bulan setelah dikeluarkan dari TPA belum mampu mengeliminasi kandungan $\mathrm{Pb}$ dalam produk sapi potong sampai aman untuk dikonsumsi.
\end{abstract}

Kata kunci: logam berat, eleminasi, sapi, pemeliharaan, konvensional

\section{Efforts of Eleminiation of Residual Heavy Metals in Beef Cattle from the Waste Disposal Site Locations With Conventional Maintenance}

\begin{abstract}
The study aimed to determine content of heavy metals $\mathrm{Pb}$ and $\mathrm{Hg}$ in the organic waste and method to eliminate the heavy metal residue of $\mathrm{Pb}$ from beef cattle products, meat and visceral organs. Two male Ongole Crossbred cattles were used in this study. Rations were given in the form of King Grass forage and commercial concentrate of Nutrifeed. The animals were kept for 3 months. At the beginning of the experiment, the fecal and blood samples were collected, then these samples were taken every two weeks. At the end of the experiment, the animals were slaughtered and meat samples of bicept femoris, liver, kidneys and intestines were taken to analyze its $\mathrm{Pb}$ content. The results showed that the organic waste contaminated with $\mathrm{Pb}$, but not contaminated with $\mathrm{Hg}$. Pb levels in blood and feces varied and quite high, whereas in beef products, meat and viscera the $\mathrm{Pb}$ were quite high and still above the safe limit for consumption. The conclusions of this experiment were that the conventional maintenance for three months after removed from the landfill was not able to eliminate the Pb content in products of beef cattle.
\end{abstract}

Key words: heavy metals, eleminiation, cattle, maintenance, conventional 


\section{PENDAHULUAN}

Usaha pengembangan populasi sapi potong, daya dukung pakan adalah sangat penting, mengingat pakan merupakan faktor utama yang menentukan produktifitas ternak disamping juga menentukan tinggi rendahnya biaya produksinya. Dalam kaitanya dengan biaya produksi, seperti diketahui bahwa biaya pakan dapat mencapai 70 - 80 persen dari biaya produksi. Berbagai upaya telah dilakukan dalam mencari alternatif pemeliharaan (budidaya) sapi potong dengan menggunakan pakan yang seefisien mungkin. Seperti misalnya penggunaan limbah pertanian dan atau limbah industri pengolahan hasilhasil pertanian, yang terbukti dapat menekan biaya pakan. Namun demikian, karena adanya kompetisi penggunaan bahan pakan tersebut dengan ternak lain seperti ternak non ruminansia dan unggas, maka harga bahan pakan mejadi lebih mahal. Upaya lain yang dapat dicoba salah satunya adalah pemeliharaan/penggembalaan sapi potong di Tempat Pembuangan Akhir (TPA) sampah.

Fakta di lapangan menunjukkan bahwa TPA sampah "Putri Cempo" Mojosongo Surakarta telah dimanfaatkan sebagai tempat penggembalaan sapi potong. Kegiatan penggembalaan sapi di TPA sampah dapat memberikan keuntungan yakni dapat memanfaatkan barang yang sudah tidak berguna (sampah organik) menjadi produk yang lebih bermanfaat dan mempunyai nilai ekonomis tinggi yakni daging sapi yang merupakan sumber protein hewani serta dapat meningkatkan pendapatan peternak melalui kepemilikan sapi potong. Tetapi disisi lain keamanan pangan dari daging sapi yang digembalakan di lokasi TPA sampah diragukan, karena dicurigai terkontaminasi logam berat. TPA sebagai tempat pembuangan berbagai macam sampah (terutama sampah anorganik) yang kemungkinan mengandung logam berat, sehingga apabila terkonsumsi oleh sapi akan terakumulasi di dalam tubuh (daging) sapi yang pada konsentrasi yang tinggi (melebihi ambang batas) akan membahayakan konsumen yang mengkonsumsi daging sapi tersebut. Hasil penelitian terdahulu (Dinas Pertanian Surakarta, 2007) diketahui bahwa sapi-sapi yang digebalakan di TPA Putri Cempo tercemar logam berat Plumbum $(\mathrm{Pb})$ dan Merkuri atau Hydrogyrum (Hg). Walaupun kadar Hg masih di bawah ambang batas toleransi sehingga aman dikonsumsi, akan tetapi kandungan $\mathrm{Pb}$ daging sapi dan organ dalam atau vicera (hati, ginjal dan usus) mengandung $\mathrm{Pb}$ di atas ambang batas aman untuk dikonsumsi. Hasil penelitian yang telah dilakukan di TPA Semarang bahwa logam berat seperti $\mathrm{Pb}, \mathrm{Hg}$ dan $\mathrm{Cd}$ dapat dieliminasi dengan cara mengkarantina sapi-sapi tersebut sebelum dipotong dengan cara memberikan pakan konvensional seperti rumput dan konsentrat.

\section{MATERI DAN METODE}

\section{Lokasi dan Waktu Penelitian}

Penelitian ini dilaksanakan di beberapa lokasi antara lain 1) TPA sampah "Putri Cempo" Mojosongo Surakarta, lokasi untuk pengambilan sampel sampah dan materi sapi potong yang akan dipelihara di laboratorium 2). Laboratorium Pengujian Veteriner Balai Besar Veteriner (BBVET), Wates Yogyakarta untuk analisis kandungan logam berat $(\mathrm{Pb}$ dan Hg) pada sampah organik dan untuk analisis kandungan logam berat $(\mathrm{Pb})$ pada feses, darah, daging, hati, ginjal dan usus sapi 3). Rumah Potong Hewan (RPH) Kota Surakarta, tempat memotong sapi-sapi setelah selesai dipelihara secara konvensional selama 3 bulan. Penelitian direcanakan memerlukan waktu 6 bulan, yang meliputi beberapa tahapan diantaranya : persiapan penelitian, analisis kandungan logam berat $\mathrm{Pb}$ dan $\mathrm{Hg}$ sampah organik, feses dan darah pada awal penelitian (sebelum dilakukan pemeliharaan secara konvensional) dan dilanjutkan setiap 2 minggu sekali untuk dianalisis Pb-nya, serta dalam daging, hati, ginjal dan usus sapi pada akhir penelitian setelah sapi-sapi dipotong , tabulasi dan analisis data serta penulisan laporan. 


\section{Materi dan Alat Penelitian}

a. Sapi, digunakan sapi potong jantan sebanyak 2 (dua) ekor umur \pm 2 tahun. masing-masing diambil dari sapi yang sejak awal (pedet) dipelihara di TPA "Putri Cempo" Surakarta

b. Pakan konvensional berupa rumput Raja (berasal dari lahan Mini Farm Jurussan/Program Studi Peternakan Fakultas Pertanian UNS di Jatikuwung), dan konsentrat komersial untuk penggemukan “Nutrifeed” (produksi KJUB Puspetasari, Klaten, Jawa Tengah)

c. Kandang beserta perlengkapannya (tempat pakan dan tempat minum) untuk proses pemeliharaan

d. Venoject, yang digunakan dalam penelitian ini adalah untuk mengambil sampel darah

e. Seperangkat alat dan kemikalia untuk analisis kandungan logam berat ( $\mathrm{Pb}$ dan Hg) sampah organik, dan khusus kandungan $\mathrm{Pb}$ feses, darah, daging, hati, ginjal dan usus sapi

\section{Jalannya Penelitian}

Persiapan penelitian dilakukan dengan cara survey ke lokasi TPA sampah "Putri Cempo" Mojosongo untuk menentukan cara pengambilan sampel sampah organik dan untuk menentukan sapi-sapi yang akan dipelihara secara konvensional di laboratorium Pengambilan sampel sampah dibedakan menurut pengelolanya. Sampah domistik yakni sampah yang dikelola oleh Dinas Kebersihan Perkotaan (DKP), sampah pasar yakni sampah yang dikekola Dinas Pengelolaan Pasar (DPP) dan sampah umum yakni sampah yang dikelola oleh masyarakat umum secara mandiri. Dari setiap jenis sampah tersebut diambil sebesar 20 persen dari frekuensi pembuangan yang dilakukan yang menggunakan armada (colt dan atau truk). Untuk armada truk diambil $50 \mathrm{Kg}$ dan untuk colt diambil $25 \mathrm{Kg}$. Sampel sampah yang diperoleh dipisahkan antara sampah organik (edible) dengan sampah anorganik (non edible). Dari sampel sampah organik (edible) diambil 10 persen untuk dikeringkan dan dilakukan komposit sebelum dilakukan analisis kandungan $\mathrm{Pb}$ dan Hg-nya

Sapi-sapi (2 ekor sampel asal TPA) dipelihara secara konvensional dengan pemberian pakan berupa rumput Raja dan konsentrat komersial (buatan pabrik). Pakan diberikan sebesar 3 \% BK berdasarkan bobot badan.

Pengambilan sampel darah dan feses dari 2 (dua) ekor sapi dimulai pada saat proses pemeliharaan (awal penelitian) dan diulang secara periodik setiap 2 minggu sekali selama 3 bulan.

Diambil dari 2 (dua) ekor sapi setelah proses pemeliharaan konvensional selesai selama 3 bulan. Sampel dari bagian sapi yang diambil adalah daging bagian Bicep femories (BF), serta organ dalam (vicera) seperti hati, ginjal dan usus.

Analisis kandungan $\mathrm{Pb}$ dan $\mathrm{Hg}$ pada sampahorganik, serta analisis $\mathrm{Pb}$ pada feses, darah, daging serta organ dalam (vicera) seperti hati, ginjal dan usus.

\section{Analisis Data}

Semua data yang diperoleh yakni, kandungan $\mathrm{Pb}$ pada sampel sampah (pakan), feses, darah dan daging, serta organ dalam (vicera) seperti hati, ginjal dan usus sapi dianalisis dan dilaporkan secara deskriptif.

\section{HASIL DAN PEMBAHASAN}

\section{Kandungan $\mathrm{Pb}$ dan $\mathrm{Hg}$ pada Sampah Organik}

Kandungan logam berat khususnya Plumbum ( $\mathrm{Pb}$ ) dan Mercury atau Hydrogyrum (Hg) hasil analisis seperti dapat dilihat pada Tabel 1.

Kandungan logam berat Timbal atau Plumbum $(\mathrm{Pb})$ dari sampah organik yang dibuang ke TPA "Putri Cempo" Surakarta sebesar 12,34 ppm.. Hasil ini hampir sama dengan yang diperoleh Muktiani, dkk (2009) yang mendapakan kandungan $\mathrm{Pb}$ pada sampah organik berkisar antara 2,4 - 13,74 ppm. Kandungan $\mathrm{Pb}$ pada sampah organik ini cukup 
Tabel 1. Kandungan Pb dan Hg Sampah Organik TPA ”Putri Cempo” Mojosongo (ppm)

\begin{tabular}{lcc}
\hline \multirow{2}{*}{ Jenis Sampah } & \multicolumn{3}{c}{ Kandungan (ppm) } \\
\cline { 2 - 3 } & $\mathbf{P b}$ & $\mathbf{H g}$ \\
\hline Sampah organik & 12,34 & $\left.<0,05^{*}\right)$ \\
\hline
\end{tabular}

Keterangan *) tidak terdeteksi dengan metode AAS

Sumber : Hasil Analisis Lab. Pengujian Veteriner, Balai Besar Veteriner, Wates, Yogyakarta (2009)

dengan jenis sampah anorganik yang dibuang ke TPA "Putri Cempo" yang kemungkinan besar sebagai faktor pencemarnya. Dari hasil penelitian ini diketahui bahwa jenis sampah anorganik yang dominan adalah plastik, kertas, kain, karet dan gelas. Sesuai dengan Anonimus (2009), bahwa di Indonesia komponen sampah anorganik yang dominan adalah kertas, plastik, logam, karet, tekstil, dan kaca/gelas. Dari tiga jenis yang paling dominan tersebut (plastik, kertas dan kain) sangat potensial sebagai pencemar logam $\mathrm{Pb}$. Seperti diketahui bahwa $\mathrm{Pb}$ merupakan salah satu komponen bahan pembuatan plastik, tinta pada kertas koran dan zat pewarna pada kain (tekstil). Seperti dinyatakan oleh Winarno (2004) bahwa para pakar lingkungan sependapat bahwa timbal atau plumbum $(\mathrm{Pb})$ merupakan kontaminan terbesar dari seluruh debu logam di udara. Lebih lanjut dinyatakan bahwa kontaminan $\mathrm{Pb}$ berasal dari industri bateray, pengolahan minyak bumi, kaleng kemasan makanan, pewarna kosmetik, keramik, dan tekstil, serta asap yang dikeluarkan dari knalpot kendaraan bermotor.

Dari hasil penelitian ini menunjukkan bahwa dari sampah organik tidak terdetekasi adanya kandungan logam berat Mercury atau Hydrogyrum (Hg). Artinya dengan penetapan menggunakan metode AAS, kandungan $\mathrm{Hg}$ kurang dari 0,05 ppm (karena batas deteksi AAS adalah 0,05 ppm). Hal ini dapat dipahami karena faktor utama pencemar $\mathrm{Hg}$ adalah limbah penambangan (tailing). Dan di wilayah kota Surakarta jauh dari aktifitas penambangan, sehingga faktor pencemar $\mathrm{Hg}$ adalah sangat kecil. Seperti diketahui bahwa $\mathrm{Hg}$ adalah unsur kimia yang termasuk logam berat dan telah lama digunakan untuk menambang emas. Karena untuk kepentingan penambangan, $\mathrm{Hg}$ dianggap mudah digunakan, relatif efisien dan harganya murah.

Hal yang sangat dikawatirkan adalah sampah-sampah organik yang telah tercemar logam berat $(\mathrm{Pb}$ maupun $\mathrm{Hg}$ ) tersebut dikonsumsi (sebagai pakan) oleh sapi-sapi potong yang digembalakan di TPA. Logam berat $(\mathrm{Pb}$ dan $\mathrm{Hg}$ ) merupakan unsur kimia yang di dalam tubuh tidak bisa dicerna dan bersifat bioakumulatif (Sinaga, 2004). Residu yang terdapat di dalam jaringan tubuh ternak (daging) akan berbahaya bila dikonsumsi oleh manusia yang mengkonsumsi. Karena dampak yang ditimbulkan dapat dirasakan bertahuntahun kemudian. Gangguan yang tibul akibat keracunan Plumbum $(\mathrm{Pb})$ adalah pada fungsi jaringan dan metabolisme, mulai dari sintesis Hemoglobin (Hb), ginjal, system syaraf, system reproduksi dan fungsi paru-paru, sedangkan akibat keracunan Mercury (Hg) dapat menimbulkan gangguan berupa rusaknya keseimbangan, tidak bisa berkonsentrasi, tuli dan gangguan seperti kasus Minamata yakni diataranya panas pada anggota badan, mulut, bibir dan lidah, serta sulit berbicara dan menelan (Sinaga, 2004), merusak sistem saraf pusat, organ-organ reproduksi, dan sistem kekebalan tubuh.

\section{Kandungan Pb pada Darah dan Feses}

Munculnya berbagai penyakit akibat kontaminasi logam berat adalah karena toksikan logam berat tersebut mempunyai kemampuan berikatan dengan enzim dengan cara menggantikan gugus logam yang berfungsi sebagai kofaktor enzim. Oleh karena itu enzim menjadi terganggu fungsinya, 
sehingga menyebabkan terganggunya proses metabolisme sebagai akibat sistem fisiologi yang tidak seimbang (Palar, 1994). Senyawa Timbal atau Plumbum $(\mathrm{Pb})$ merupakan senyawa logam berat yang terdapat di alam dan berbahaya bagi kesehatan manusia bila terkonsumsi. Hal ini terjadi karena logam berat dalam tubuh bersifat akumulatif (bioakumulatif). Senyawa logam berat $\mathrm{Pb}$ banyak dipakai di dalam kegiatan industri khususnya sebagai campuran dalam pembuatan alat-alat rumah tangga seperti alatalat elektronik, plastik, cat, pewarna, bensin, mainan anak-anak, dan lain-lain. Senyawa logam berat $\mathrm{Pb}$ masuk ke dalam tubuh melalui makanan, minuman, udara dan air yang terkontaminasi logam berat tersebut. Kandungan Plumbum $(\mathrm{Pb})$ dalam darah dan feses pada sapi potong yang digembalakan di TPA "Putri Cempo" Mojosongo seperti terlihat pada Tabel 2.

Dari tabel 2 terlihat bahwa kandungan Plumbum $(\mathrm{Pb})$ darah dan feses pada sapi potong yang digembalakan di TPA "Putri Cempo" Mojosongo sangat bervariasi. Namun demikian khususnya 4 minggu terakhir ada kencenderungan lebih rendah dari mingguminggu sebelumnya. Variasi (naik turunnya) kadar $\mathrm{Pb}$ pada feses dan darah kemungkinan disebabkan karena di dalam lambung sapi (khususnya rumen) terakumulasi sampah plastik yang ikut terkonsumsi oleh sapi saat mencari pakan di TPA. Sampah-sampah plastik yang terkonsumsi tersebut tidak dapat dicerna dan bahkan tidak dapat dikeluarkan bersama feses. Bahkan kadang-kadang terbawa saat eruktasi dan keluar melalui mulut (terjadi saat dipelihara di laboratorium). Bukti lain setelah dipotong dan dilakukan pembedahan lambung, maka di dalam lambung sapi sangat banyak dijumpai sampah plastik tersebut. Oleh karena itu, walaupun sudah tidak mendapatkan pakan yang berupa sampah organik dari TPA yang kandungan $\mathrm{Pb}$ cukup tinggi (Tabel 1), tetapi kadar $\mathrm{Pb}$ darah dan feses masih cukup tinggi. Hal ini karena masih tercemar oleh sampah plastik yang terdapat dalam lambung sapi tersebut. Seperti dinyatakan bahwa sumber pencemar $\mathrm{Pb}$ salah satunya adalah plastik (Anonimus, 2009). Terlihat bahwa, secara umum 4 minggu terakhir (2 kali pengambilan sampel) kadar $\mathrm{Pb}$ pada darah dan feses cenderung lebih rendah dari sebelumnya. Hal ini kemungkinan karena kontaminan terutama dari sampah plastik yang ada di dalam lambung telah berkurang.

\section{Kandungan $\mathrm{Pb}$ pada Daging dan Organ Dalam (Vicera)}

Kandungan Plumbum (Pb) dalam darah dan organ dalam (vicera) pada sapi potong yang. digembalakan di TPA "Putri Cempo" Mojosongo se perti terlihat pada Tabel 3.

Kandungan Plumbum $(\mathrm{Pb})$ dari produk sapi potong yang berupa daging dan organ dalam (vicera) di atas ambang batas toleransi yang aman dikonsumsi sesuai Standar Nasional Indonesia (SNI) bahwa kandungan $\mathrm{Pb}$ makanan atau minuman maksimal 2,0 $\mathrm{mg} / \mathrm{kg}$ (2,0 ppm). Dengan kata lain bahwa produk sapi potong yang digembalakan di TPA ”Putri Cempo" Mojosongo kurang aman untuk dikonsumsi. Hasil ini merupakan hasil setelah dilakukan proses pemeliharaan di luar TPA dan diberikan pakan konvensional berupa rumput Raja dan konsentrat komersial. Tingginya kandungan $\mathrm{Pb}$ dalam produk sapi potong tersebut diduga kerena kandungan $\mathrm{Pb}$ sebelum dikeluarkan dari TPA sudah tinggi, sehingga walaupun sudah dikeluarkan dari TPA dan dipelihara secara konvensional dan terjadi penurunan kandungan $\mathrm{Pb}$, tetapi hasil akhir kandungan Pb-nya masih tinggi. Seperti diketahui logam berat termasuk $\mathrm{Pb}$ tidak dapat dicerna dan bersifat bioakumulatif di dalam tubuh (Sinaga, 2004). Disamping itu, jika dikaitkan dengan kandungan $\mathrm{Pb}$ dalam darah dan feses juga terlihat cukup tinggi, yang kemungkinan disebabkan karena kontaminan dari sampah plastik yang terakumulasi di dalam lambung sapi. Plastik sebagai pencemar $\mathrm{Pb}$ tidak dapat dicerna dan tidak dapat dikeluarkan dari dalam lambung. Faktor inilah yang juga dimungkinkan penyebab masih tingginya kandungan $\mathrm{Pb}$ pada produk sapi potong tersebut. 
Tabel 2. Kandungan Plumbum $(\mathrm{Pb})$ dalam darah dan feses sapi potong yang digembalakan di TPA "Putri cempo" (ppm)

\begin{tabular}{|c|c|c|c|c|c|c|c|c|c|}
\hline \multirow{2}{*}{ Organ } & \multirow{2}{*}{ Sapi } & \multicolumn{7}{|c|}{ Kadar Pb } & \multirow[t]{2}{*}{ SNI (ppm) } \\
\hline & & $\mathrm{I}$ & II & III & IV & $\mathrm{V}$ & VI & VII & \\
\hline \multirow[t]{2}{*}{ Darah } & 1 & $-*)$ & 2,29 & 4,72 & 0,80 & 1,51 & 0,14 & 0,78 & 2,0 \\
\hline & 2 & $-*)$ & 0,72 & 4,41 & 1,07 & 2,25 & 0,58 & 0,64 & 2,0 \\
\hline \multirow[t]{2}{*}{ Feses } & 1 & 2,76 & 4,14 & 1,56 & 1,44 & 1,95 & 1,42 & 1,27 & 2,0 \\
\hline & 2 & 0,71 & 5,63 & 3,57 & 0,64 & 4,01 & 2,09 & 1,30 & 2,0 \\
\hline
\end{tabular}

Keterangan : *) tidak terdeteksi karena sampel terlalu sedikit (sampel darah sulit diperoleh)

Sumber $\quad$ : Hasil Analisis Lab. Pengujian Veteriner, Balai Besar Veteriner, Wates, Yogyakarta (2009)

Tabel 3. Kandungan Plumbum (Pb) dalam daging dan organ dalam (vicera) sapi potong yang digembalakan di TPA "Putri cempo" (ppm)

\begin{tabular}{lccc}
\hline \multicolumn{1}{c}{ Organ } & Sapi & Kadar Pb & SNI (ppm) \\
\hline Daging & 1 & 3,6 & 2,0 \\
\multirow{3}{*}{ Ginjal } & 2 & 4,6 & 2,0 \\
& 1 & 2,7 & 2,0 \\
\multirow{2}{*}{ Hati } & 2 & 2,8 & 2,0 \\
& 1 & 3,2 & 2,0 \\
Usus & 2 & 2,9 & 2,0 \\
& 1 & 2,97 & 2,0 \\
& 2 & 3,96 & 2,0 \\
\hline
\end{tabular}

Sumber $\quad$ : Hasil Analisis Lab. Pengujian Veteriner, Balai Besar Veteriner, Wates, Yogyakarta (2009)

Kondisi ini semakin dipahami jika dilihat dari hasil sampling jenis/macam sampah (anorganik) yang di buang di TPA "Putri Cempo" yang didominasi oleh sampah plastik, kertas (koran) dan kain. Ketiga bahan tersebut berpotensi sebagai pencemar karena senyawa logam digunakan dalam proses pembuatan barang-barang tersebut. Plastik, kertas koran (tintanya) dan kain (zat pewarnanya) mengandung senyawa $\mathrm{Pb}$.

\section{KESIMPULAN}

Sampah organik yang dibuang ke Tempat Pembuangan (TPA) sampah "Putri Cempo" Mojosongo Surakarta tercemar logam berat Plumbum $(\mathrm{Pb})$, tetapi tidak tercemar Logam Merkuri (Hg).

Pemeliharaan konvensional selama 3 bulan setelah dikeluarkan dari TPA belum mampu mengeliminasi logam $\mathrm{Pb}$ sampai di bawah ambang batas toleransi untuk aman dikonsumsi.

\section{DAFTAR PUSTAKA}

Anggorodi, R. 1990. Ilmu Makanan Ternak Umum. PT Gramedia. Jakarta.

Anonimus. 2004. Bahaya Cemaran Logam Berat. Pikiran Rakyat, 29 Juli 2004.

Anonimus. 2006. Sapi Tercemar Logam Berat. Kompas, 18 September 2006.

Anonimus, 2009. Modul Pelatihan 3 R. Direktorat Pengembangan Penyehatan.

Lingkungan Pemukiman. Direktorat Jendral Cipta Karya. Departemen Pekerjaan Umum. akarta.

Bahar, Y.H. 1986. Teknologi Penanganan dan Pemanfaatan Sampah. PT.Waca Utama Pramesti. Jakarta

Badan POM RI. 2003. Peraturan di Bidang Pangan. Dit.Surveilan dan Penyuluhan Keamanan Pangan. Deputi Bidang Pengawasan Keamanan Pangan dan Bahan Berbahaya. Jakarta

Cullison, A.E. 1979. Feed and Feeding. 2nd eds. Reston Publ. Co., Ic. Reston, Virginia. 
Dinas Pertanian Surakarta, 2007. Studi Kandungan Residu Logam Berat pada Sapi Potong di TPA Kota Surakarta. Dinas pertanian . pemerintah Kota Surakarta.

Dyer, I.A. and R.P. Kromann. 1977. Cattle Feeding. In : The Feedlot. Dyer, I.A and C.C.O. Marry ed. Lea ad Febiger. Philadelphia

Irawati, D.A. 1999. Kinerja Sapi Peranakan Ongole yang Digembalakan di Lokasi Tempat Pembuangan Akhir Mojosongo Surakarta. Tesis S-2. Program Pasca Sarjana UGM. Yogyakarta.

Muktiani, A., B. I. Moeda T., dan J. Achmadi 2009. Potensi Sampah Organik sebagai Pengganti Rumput ditinjau dari Parameter Metabolisme Rumen secara in Vitro dan Kandungan Logam Berat Timbal (Pb) . http://www.lemlit. undip.ac.id/ abstrak/ content/view/123/281/ (Akses, 21 Oktober 2009)

NRC, 1976. Nutrient Requirement of Beef Cattle. 5th eds. National Academy of Sciences. Washington.

Palar, H. 1994. Pencemaran dan Toksikologi Logam Berat. Cetakan I. Rineka Cipta. Jakarta

Payne, W.J.A. 1970. Cattle Production in the Tropic. Longmann Group Ltd. London.

Sinaga, S.M. 2004. Perspektif Pengawasan Makanan dalam Kerangka Keamanan Makanan dan untuk Meningkatkan Kesehatan. Pidato Pengukuhan Jabatan Guru Besar Tetap F.MIPA. USU. Medan

Tillman, A.D. 1987. Bangsa-bangsa Ternak di Indonesia dan Hasilnya. Dalam : Pengembangan Peternakan di Indonesia. P.S.Hardjosworo dan J.M. Levine Editor. Yayasan Obor Indonesia. Jakarta.

Tillman, A.D., H.Hartadi dan R. Reksohadiprodjo, 1991. Ilmu Makanan Ternak Dasar. Gadjah Mada Univ. Press. Yogyakarta.

Winarno, F.G. 2004. Keamanan Pangan. M-Brio Press. Bogor. 